\title{
Sustaining Welfare for Future Generations: A Review Note on the Capital Approach to the Measurement of Sustainable Development
}

\author{
Thorvald Moe ${ }^{1}$, Knut H. Alfsen ${ }^{1, *}$, Mads Greaker ${ }^{2}$ \\ ${ }^{1}$ Center for International Climate and Environmental Research Oslo (CICERO), P. O. Box 1129, Blindern, \\ 0318 Oslo, Norway; E-Mail: kal@cicero.oslo.no (K.H.A.); Tel.: +47 22858569; Fax: +47 22858751 \\ ${ }^{2}$ Research Department, Statistics Norway, P. O. Box 8131, Dep, 0033 Oslo, Norway \\ * Corresponding author
}

Submitted: 8 January 2013 | In revised form: 28 March 2013 | Accepted: 22 April 2013 |

Published: 12 May 2013

\begin{abstract}
Measuring sustainable development based on analytical models of growth and development and modern methods of growth accounting is an economic approach-often called the capital approach - to establishing sustainable development indicators (SDIs). Ecological approaches may be combined with the capital approach, but there are also other approaches to establishing sustainable development indicators-for example the so-called integrated approach. A recent survey of the various approaches is provided in UNECE, OECD and Eurostat [1]. This review note is not intended to be another survey of the various approaches. Rather the objective of this paper is twofold: to present an update on an economic approach to measuring sustainable development-the capital approach-and how this approach may be combined with the ecological approach; to show how this approach is actually used as a basis for longer-term policies to enhance sustainable development in Norway-a country that relies heavily on non-renewable natural resources. We give a brief review of recent literature and set out a model of development based on produced, human, natural and social capital, and the level of technology. Natural capital is divided into two parts-natural capital produced and sold in markets (oil and gas)-and non-market natural capital such as clean air and biodiversity. Weak sustainable development is defined as non-declining welfare per capita if the total stock of a nation's capital is maintained. Strong sustainable development is if none of the capital stocks, notably non-market natural capital, is reduced below critical or irreversible levels. Within such a framework, and based on Norwegian experience and statistical work, monetary indexes of national wealth and its individual components including real capital, human capital and market natural capital are presented. Limits to this framework and to these calculations are then discussed, and we argue that such monetary indexes should be sustainable development
\end{abstract}

(C) 2013 by the authors; licensee Librello, Switzerland. This open access article was published under a Creative Commons Attribution License (http://creativecommons.org/licenses/by/3.0/). 
indicators (SDIs) of non-market natural capital, and physical SDIs, health capital and social capital. Thus we agree with the Stiglitz-Sen-Fitoussi Commission [2] that monetary indexes of capital should be combined with physical SDIs of capital that have no market prices. We then illustrate the policy relevance of this framework, and how it is actually being used in long term policy making in Norway-a country that relies heavily on non-renewable resources like oil and gas. A key sustainability rule for Norwegian policies is to maintain the total future capital stocks per capita in real terms as the country draws down its stocks of non-renewable natural capital —applying a fiscal guideline akin to the Hartwick rule.

Keywords: capital approach; indicators; national wealth; sustainable development

\section{Introduction}

Twenty-five years after the World Commission on Environment and Development (WCED) published the book Our Common Future [3], there is an emerging view in economic literature on sustainable development that one should focus on sustaining wellbeing per capita in real terms for future generations, and that analyses of measurement and policies should be based on analytical models of growth and development and modern wealth accounting.

Thus, a main message from the Stiglitz, Sen and Fitoussi Report from 2009 is:

The report distinguishes between an assessment of current well-being and an assessment of sustainability. Current well-being has to do with both economic resources, such as income, and with non-economic aspects of peoples' life (what they do and what they can do, how they feel, and the natural environment they live in). Whether these levels of well-being can be sustained over time depends on whether stocks of capital that matter for our lives (natural, physical, human, social) are passed on to future generations ([2], p. 11).

However, there are other approaches to defining and measuring sustainable development. In a recent report from UNECE, OECD and Eurostat [1] differences of views are described thus:

One view, referred to as the integrated view, held that the goal of sustainable development is to ensure both the well-being of those currently living and the potential for the well-being of future generations. The second approach is that the concern for sustainable development is properly limited to just the latter.

For a survey of both "economic and non-economic" approaches, the reader is referred to this report.

An illustration of the difference between empirical work based on the integrated approach and work based on the capital approach is whether one should include estimated gross domestic product, GDP, as an indicator of sustainable development or not. According to present national accounting conventions, the use of non-renewable natural resources is not deducted when GDP is estimated. Thus, one may boost GDP by rapidly drawing on such resources, but if the revenues are spent on consumption rather than building up other types of capital, the country in question may be worse off in the medium or longer term as their stock of capital or wealth is reduced. Sustainable indicator sets using GDP based on an integrated approach may thus be misleading to policy makers. GDP is a measure of economic welfare in the short term, but not an indicator of sustainable development.

Finally, the World Bank put forward the view:

Conceive of development as a process of building and managing a portfolio of assets. The challenge of development is to manage not just the total volume of assets - how much to save versus how much to consume - but also the composition of the asset portfolio, that is, how much to invest in different types of capital, including the institutions and governance that constitute social capital ([4], p. 4).

Instead of using GDP one may use Adjusted Net savings (ANS) as a macro indicator of sustainable development as presented by The World Bank. ANS, also called genuine saving, is defined as national saving adjusted for the value of resource depletion and environmental degradation and credited for education expenditures (a proxy for investment in human capital). Since wealth changes through saving and investment, ANS measures the change in a country's national wealth, see [4].

In section 2 we elaborate on our analytical framework based on the capital approach, and in section 3 we illustrate the current measurement of the economic elements in our model of development with reference to current wealth accounting practices in Norway.

We argue, furthermore, that measures of economic or national wealth in monetary terms have their limits, and one thus needs a few indicators in physical terms of non-economic aspects of development, such as critical elements of non-market natural capital and 
health and social capital in order to make a comprehensive assessment of whether a country is on a sustainable path.

A main reason for measuring the main elements that drive development over time is to inform policy. In section 4 we illustrate how our analytical framework and SDIs are actually used for policymaking in Norway, which is a resource-producing country with large reservoirs of non-renewable, or exhaustible resources, in its oil and gas sector. Section 5 concludes.

\section{The Analytical Framework}

In the 1970s economists reacted to the challenge of OPEC and the "doomsday predictions" of the Club of Rome by introducing energy, natural resources and environmental pollution into the neoclassical theory of growth. In the 1990s they reacted to global climate change and the Report of the Brundtland Commission [3] by introducing the same considerations into the theory of endogenous growth.

Economic growth involves a two-way interaction between technology and economic life: technological progress transforms the very economic system that creates it. The purpose of endogenous growth theory is to seek some understanding of this interplay between technological knowledge and various structural characteristics of the economy and society, and how such interplay results in economic development. According to Aghion and Howitt [5], endogenous growth theory is inherently more suitable for addressing the problems of sustainable development than neoclassical theory, because the central question to which endogenous growth theory is addressed is whether or not growth can be sustained. See [5], especially chapter 5.

We take the view that economic development should be evaluated in terms of its contribution to intergenerational well-being. Specifically, we identify sustainable development paths along which intergenerational well-being per capita in real terms do not decline. The idea that movements in wealth should be used to judge the sustainability of development paths was put forward by Pearce and Atkinson [6], who defined sustainable development to be an economic path in which (comprehensive) wealth does not decline. The connections between movements in wealth and changes in intergenerational well-being or welfare were identified independently by Hamilton and Clemens [7] and Dasgupta and Mäler [8]. For further discussions of criteria for sustainable development, see [9-11].

According to [8] welfare is very closely related to what we think of as wealth, as wealth represents the totality of resources upon which we are able to draw to support ourselves over time. From this it is clear that welfare is a forward looking concept in which what counts is not how well off we are today, but our prospects for being well off in the future. In other words, welfare is an intertemporal concept.

As for well-being, there seems to be no single definition, and there remains a considerable debate regarding its determinants. Some use it synonymously with welfare. Others, including Dasgupta, claim that well-being encompasses welfare but goes beyond it to include benefits derived from things other than consumption, for example human rights. While the formal distinction may continue in academic debates, it is not of great importance for the discussion in this paper. For this reason, and because it may be the more encompassing term, well-being is the term used in this paper.

A large number of empirical econometric tests confirm the importance of technological change and resulting productivity increases for growth and development. We observe, for example, steady energy efficiency improvements over an extended period in most OECD countries. Thus, we include the level of technology, $\mathrm{TL}$, in our model. Our analytical framework for explaining longer-term development of wellbeing can be summarized thus:

$$
W B=f(R C, H C, N C, H S C, T L)
$$

where:

$\mathrm{WB}=$ Well-being;

$\mathrm{RC}=$ Real or produced capital;

$\mathrm{HC}=$ Human capital;

$\mathrm{NC}=$ Natural capital which has two main elements, resources sold in markets-Market Natural Capital MNC, and Non-Market Natural Capital NMNC (clean air, biodiversity);

HSC = Health and Social capital;

$\mathrm{TL}=$ The level of technological knowledge.

In standard wealth accounting, National Wealth, NW equals the stocks of capital, thus the definitional equation:

$$
N W=R C+H C+M N C+N M N C+H S C
$$

and thus:

$$
W B=f(N W, T L)
$$

Development of well-being is a function of the stock of national wealth, NW, and the level of technology, TL.

In literature, weak sustainable development, WSD, is total real NW per capita not declining over time. Strong sustainable development, SSD, requires that none of the individual capital components, i.e. RC, HC, MNC, NMNC and HSC, are reduced below critical or irreversible levels. For further discussion of criteria for sustainable development, see for example Pearce and Atkinson [10] and Alfsen and Moe [11].

Whether economic development will be sustainable in the longer term may, in the final analysis, depend on technological developments, see Aghion and 
Howitt [5], chapter 5, and Hamilton and Atkinson [12], chapter 8 . We return to this issue in section 3.4 below.

The criteria for assessing sustainable development should then be that national wealth per capita in real terms and adjusted for productivity growth should be non-declining, and that none of the components in equation 2 above is reduced below critical or irreversible levels.

\section{Measurement}

The Stiglitz Commission ([2], recommendation 11, p.17) recommends:

Sustainability assessment requires a well-defined dashboard of indicators. The distinctive feature of components of this dashboard should be that they are interpretable as variations of some underlying stocks. A monetary index of sustainability has its place in such a dashboard but, under the current state of the art, it should remain focused on economic aspects of sustainability.

We now have fairly well developed methods for such monetary indexes, i.e. measurement methods for economic wealth, EW, cfr. section 3.1 below.

\subsection{Monetary Indexes of Economic Wealth (EW)}

Norway has been a resource-producing country for a long time, and wealth accounting goes back to the 1980s. Present methods used and presented regularly in order to inform policy are presented below.

Calculating Economic Wealth goes through three steps.

\subsubsection{STEP 1: Calculating Resource Rents}

The first step, based on an approach by Eurostat [13] and the United Nations et. al. [14], is to calculate the resource rents from market based natural resources, MBNC.

\footnotetext{
Resource rent $=$

Value of production

\pm Product specific taxes/subsidies

- Raw materials

- Wage payments and capital costs

\pm Not sector specific taxes/subsidies
}

\subsubsection{STEP 2: Decomposing Net National Income (NNI)}

The next step is to decompose the observed net national income, NNI, on returns from the various types of capital.
$N N I=$

Resource rents from non-renewable natural resources (oil and gas, etc.)

+ Resource rents from renewable resources (fish, agriculture, forestry, etc.)

+ Return on real capital calculated as an average rate of return on the total capital stock

+ Net income from financial wealth

\pm A residual containing return on human (and social) capital as well as income from natural capital not captured in the resource rent calculations

\subsubsection{STEP 3: Converting Streams Into Wealth}

The third step is to convert future income streams of income into (stocks of) Economic Wealth (EW):

Economic Wealth $(E W)=$

Present value of future resource rents of non-renewable resources

+ Present value of future resource rents from renewable resources

+ Real capital stock

+ Present value from future returns on human capital

+ Net foreign assets

For further details and concrete calculations of EW in Norway, see Alfsen and Moe ([11], pp. 14-17).

Figure 1 shows development over time of the renewable natural capital of Norway.

Note that "agriculture" has a negative value. This follows from the definition of resource rents, and the extensive subsidizing of the sector, that is, all product specific subsidies should be treated as a cost of production. Note also that hydropower has had a significantly higher value for the last 8 years. This is most often explained by the liberalizing of the power sector in Norway. Finally, note that all in all the management of the renewable natural resources seems to be improving. A majority of the natural resources have a positive rent, and the negative rents in agriculture are becoming less prominent.

Figure 2 shows the development in the components of national wealth (NW) in Norway from 1985 to 2011.

Non-renewable resources consist of oil, natural gas and mining, however, mining is only a tiny fraction of the total value (close to zero on average). We further note that the value of the non-renewable resources has been declining since 2004. The rent has however been invested in a fund, The State Pension FundGlobal, which transforms revenue from non-renewable resources to financial capital abroad according to sustainability criteria elaborated on in section 4 below; note the yellow bar.

Dividing total national wealth by the population gives national wealth per capita, see Figure 3 . 


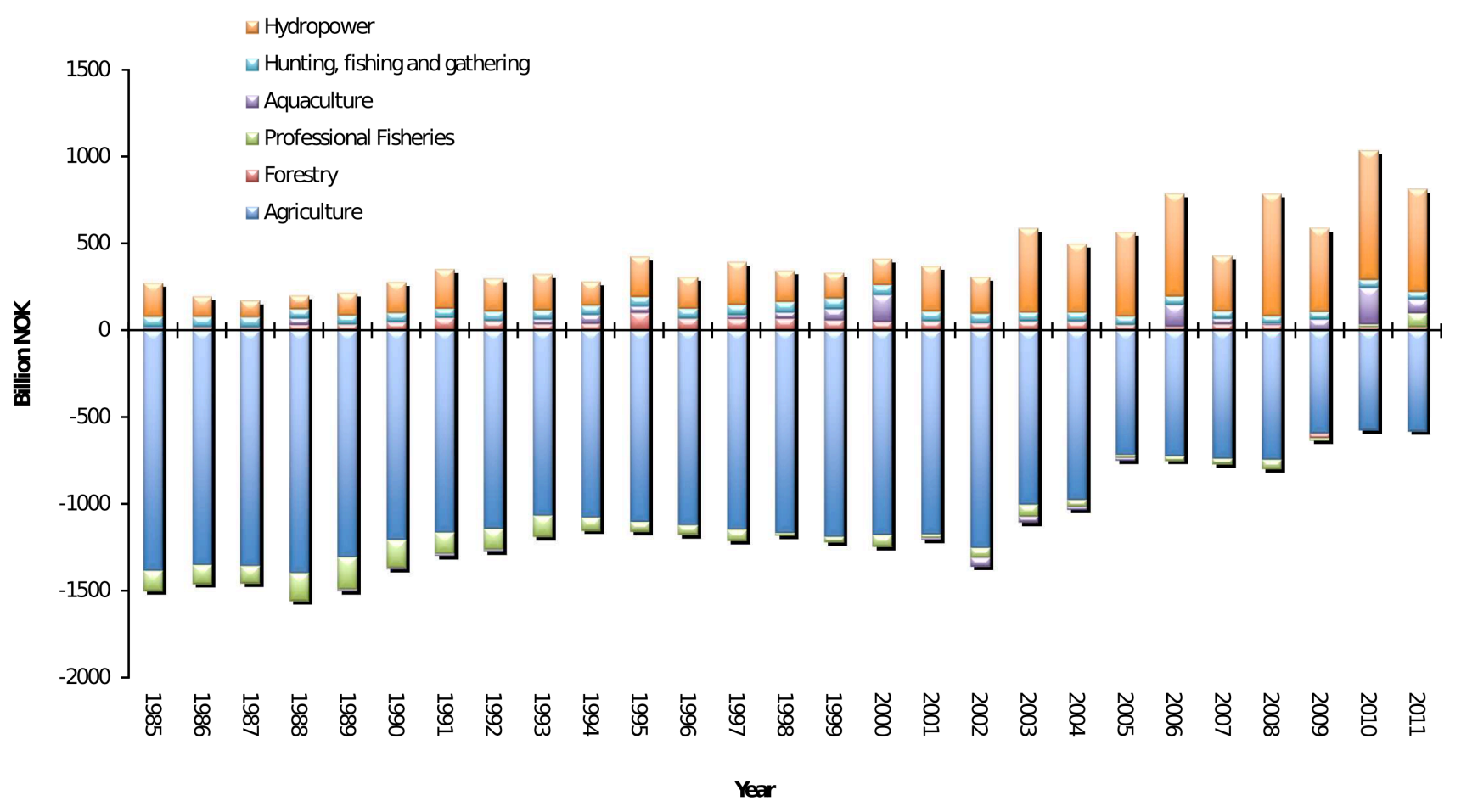

Figure 1. Development of renewable natural capital in Norway 1985-2011.

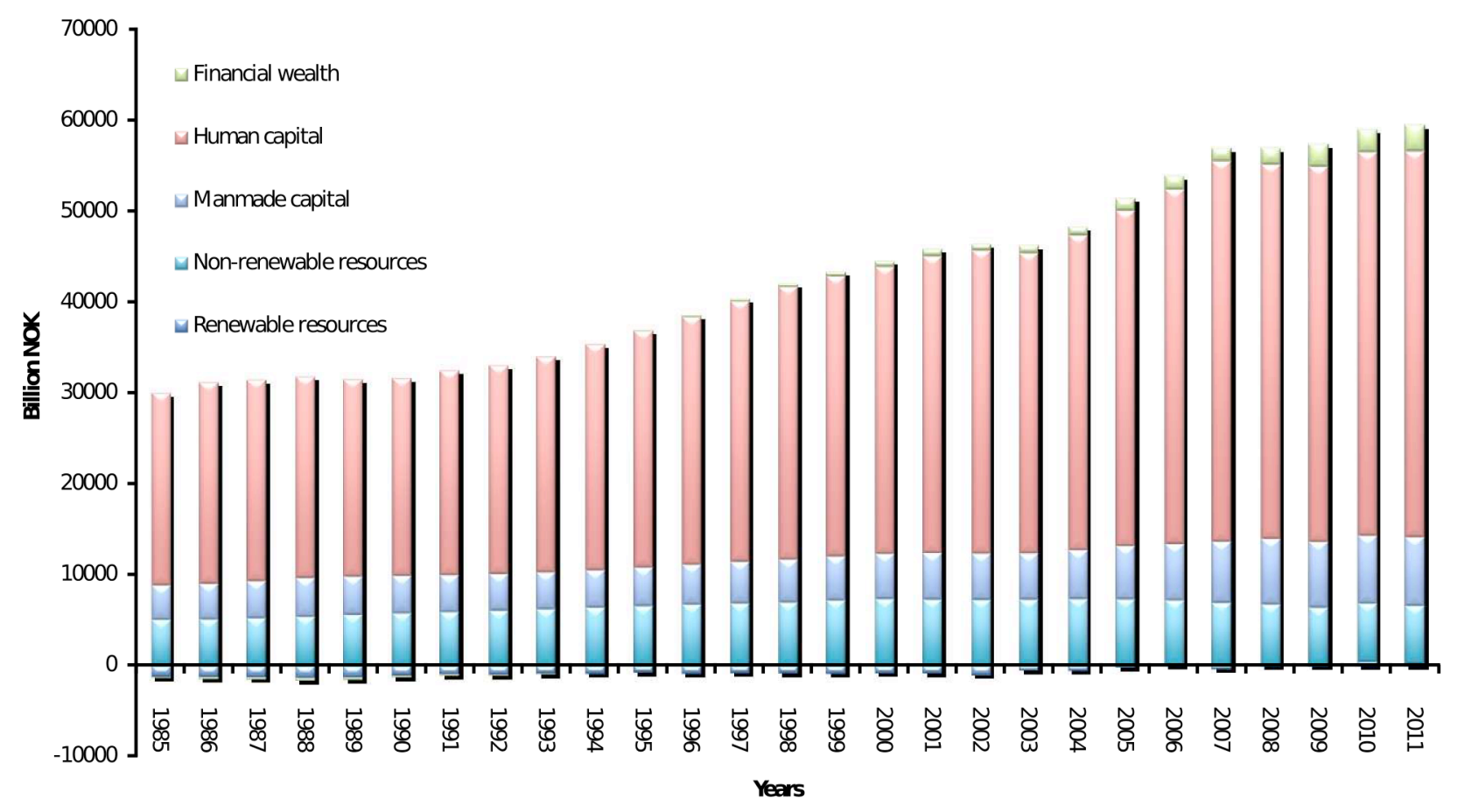

Figure 2. Decomposed national wealth (NW) in Norway 1985-2011 


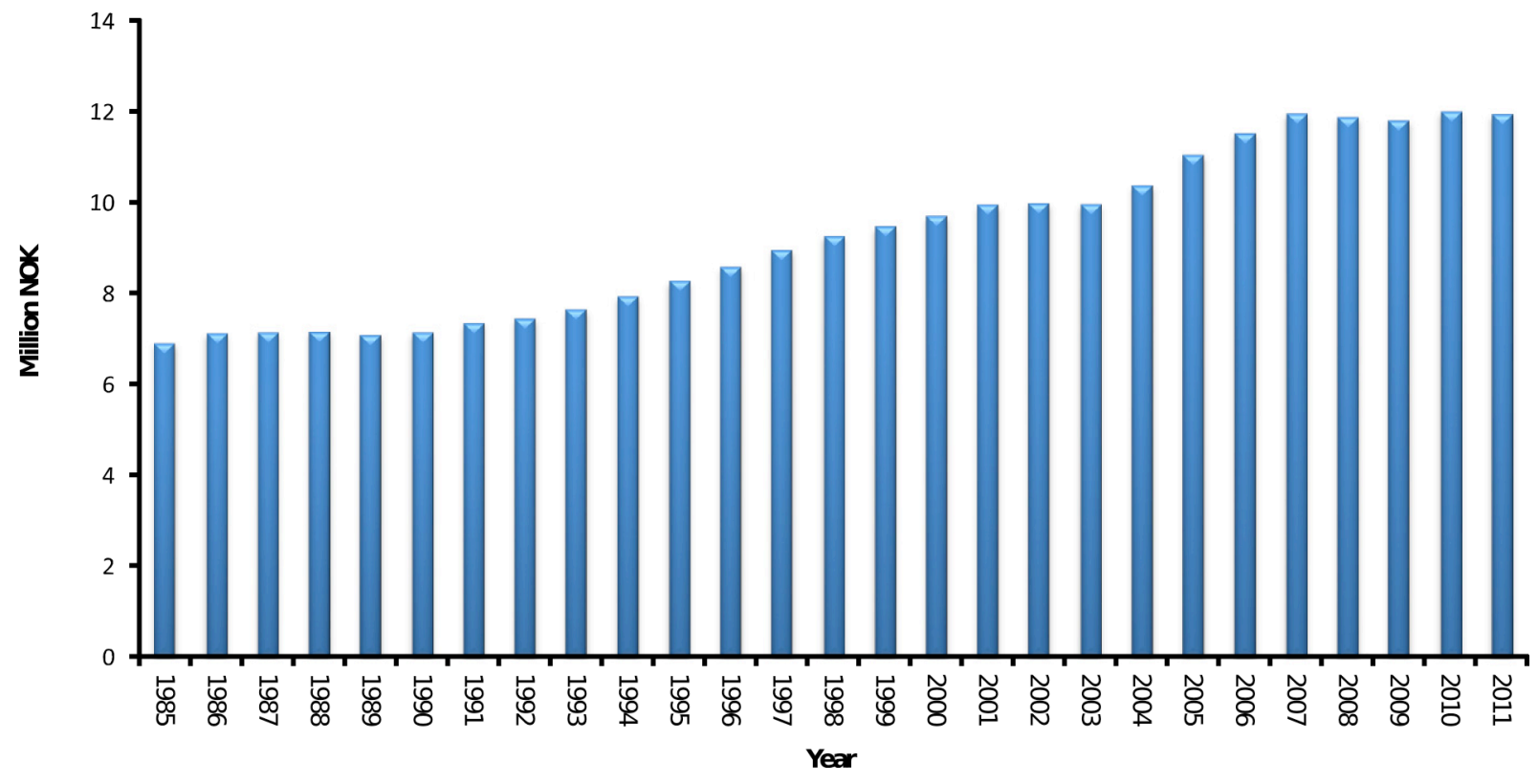

Figure 3. Development of national Economic Wealth per capita in Norway 1985-2011.

National wealth per capita has been increasing for most of the period, despite a large increase in population due to migration. Our measurements appear to be stabilizing at 12 million NOK per capita. In order to ensure sustainability, development must be followed closely. Human capital, the largest component of total economic wealth, was earlier arrived at as a residual, i.e. something that cannot be measured directly, however, in recent years great strides have been made in methods for direct calculations of human capital, and we now turn to this topic.

\subsection{Direct Measurement of Human Capital}

An improvement and further development of this established wealth accounting procedure is to estimate the stock of human capital directly using one of the following alternative methods, see Jorgensen and Fraumeini [15], Stroombergen et al. [16], Greaker [17] and Greaker and Lui [18]:

- The cost based method that measures human capital from the input side (how much is spent on education, etc.);

- The revenue generating method that estimates human capital from the output side (e.g. increased wages due to improved education and skills).

Recently the UNECE Conference of European Statisticians (CES) prepared a stock taking report providing an overview of what has been done in the field of human capital measurement [19].

The concept of human capital is broad, encompassing a range of personal attributes, such as people's health conditions. The OECD [20] has gradually extended its definition of human capital to:
The knowledge, skills, competencies embodied in individuals that facilitate the creation of personal, social and economic well-being.

A pragmatic approach to estimate stocks of human capital in monetary terms focuses on economic returns, and implies that the health component of human capital will have to be dealt with separately from the education aspect.

The income-based approach measures human capital by looking at the stream of future earnings that human capital investment generates over the life time of a person. Hence, in contrast with the costbased approach, which focuses on the input side, the income-based approach measures the stock of human capital by looking at the output side. However, outputs from human capital investment may be of many types (i.e. monetary and non-monetary, private and public), and the output measured by the life time approach is limited to the private monetary benefits that a person investing in human capital accrues.

Some developed countries now, more or less, regularly compute numbers for human capital stocks in monetary terms (although not as part of official statistics), and such calculations have been carried out in Norway for some time.

Figure 4 shows estimated returns to human capital in Norway compared to total wages paid.

\subsection{Indicators in Physical Terms for the Non-Market Elements of Natural Capital}

There are limits to the capital approach and the monetization of indexes of capital stocks. Thus, ecological approaches have their place in assessing what we have called non-market natural capital: they 


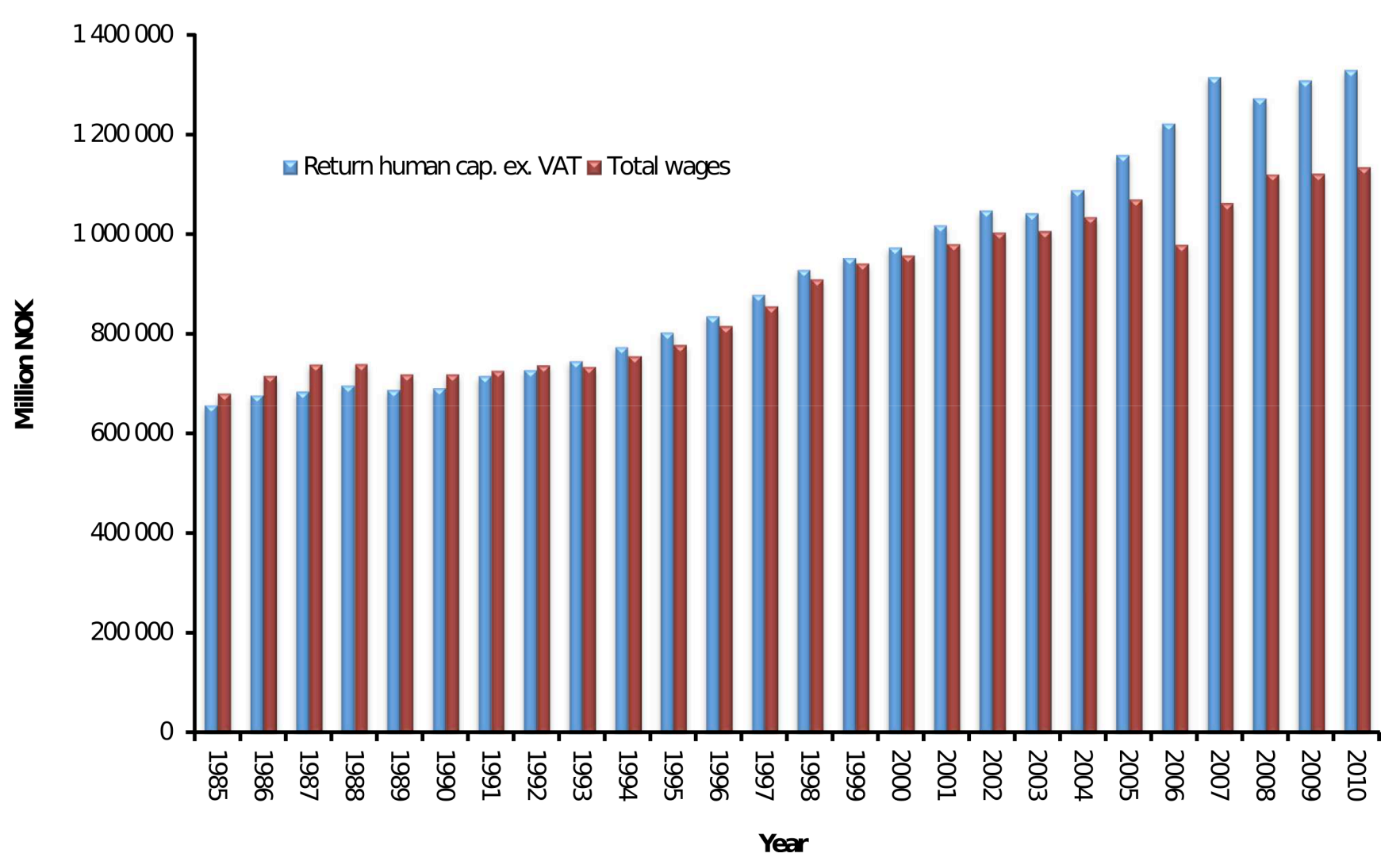

Figure 4. Estimated returns to human capital in Norway compared to total wages paid 1985-2011.

relate to the ability of the environment to sustain essential ecological resources and functions. See Pearce and Barbier [21], chapter 5. Recently Rockstrøm et al. [22] have proposed a framework based on planetary boundaries. These boundaries define the safe operating space for humanity with respect to the Earth system and are associated with the planet's biophysical subsystems or processes.

A main category in which critical assets are found is natural capital, as it is here where the assets that are essential for basic life reside. Although there remain scientific debates as to just which (largely nonmarket) assets are critical, and which are not, there is reasonable consensus that the following are very important, if not essential:

- A reasonably stable and predictable climate;

- Air that is safe to breathe;

- High-quality water in sufficient quantities;

- Areas of intact natural landscapes;

- A diversity of plant and animal life.

Some of the assets on this list may in fact be valued in monetary terms, although this is usually done in articles in research literature and more seldom in connection with wealth and sustainable development accounting. For example, it is difficult to put a reasonable monetary value on the stock of clean air, but we can put a value on the quantity of particulates in the air because we can value the associated health damages in the exposed population (and similarly for water pollutants, although here the question of exposure is more complicated). Intact natural landscapes can be valued in terms of the environmental services they provide to other assets and in terms of our willingness to pay to enjoy them (or simply to know that they exist)-not easy to value, but we know broadly how to do it. However, until such methods are refined and widely accepted, there remains the need for a few physical indicators. One should also account for the fact that some capital assets contribute to well-being outside the market place. While this is not a concern for produced capital, it may be for human, natural and social capital.

Non-market natural capital contributes to the wellbeing outside the market when people experience nature directly or when they derive pleasure from the knowledge that nature continues to exist in a reasonable condition. In principle, the well-being associated with the use of non-market natural capital may be valued in monetary terms. In practice, however, the scope for actually estimating such values in monetary terms is limited, and any such monetary indicator may underestimate welfare. As of now, some physical indicators are called for to assess the extent to which the non-market components of natural capital are, or are not, approaching critical or irreversible values. 


\subsection{Health Capital, Social Capital, Population and Technology}

As mentioned in section 3.2, the health aspects of human capital are not included in the direct measures presented of stocks of human capital. An increase in life expectancy translates into improved health. More specifically, the value of health improvements may be defined as the value that people attach to the additional years of life that result from such improvements.

Arrow et al. [23] calculate the monetary value of an additional year of life by starting with estimating the value of a statistical life (VSL). A common method for estimating VSL is to study differential wages for jobs involving differential risks of a fatal on-the-job accident. For more details, see section 4.3.2 of their paper, but also comments by Hamilton [24].

If one thinks this is complicated, or if one finds it difficult to put monetary values on an extra year of life, one may simply use a physical indicator of the life expectancy at birth-which is readily available in many countries. This is done in the Norwegian SDI set.

Social conditions, governance and institutions are important factors for development. Whether such factors are critical for sustainable development is not clear, but indicators for such factors are needed. D'Ercole and Salvini [25] argue plausibly that social welfare systems are important. The World Bank [4], [26] in their estimates of Adjusted Net Saving refer to intangible capital as a residual. In the Norwegian core sustainable development indicator (SDI) set, one uses a physical indicator of the share of people of working age that are receiving non-working benefits (disability and long-term unemployment benefits) compared to the total population in the labour force - as the share is large and increasing it poses a challenge to the future labour supply and to government finances.

Population is a capital asset. It could seem intuitive that when population size changes the criterion for sustainable development should be non-declining comprehensive wealth per capita. Arrow et. al. [23] identify conditions under which this intuition actually holds true, and in their empirical calculations they simply adjust changes in wealth between two time periods (which they call comprehensive investment) for population growth in the same period.

As previously mentioned, Aghion and Howitt [5] explore the role of technology using endogenous growth models as an aid. Their general conclusion is that:

The chances of achieving sustainable growth depend critically on maintaining a steady flow of technological innovations ([5], p. 151).

Hamilton and Atkinson [12], chapter 8, discuss the role of total productivity growth or future technological developments for sustainable development and present estimates for a number of countries. Their results depend heavily on whether technological improvements are assumed to be exogenous and costless or endogenous; this being of far greater importance in the first case.

According to Acemoglu et al.:

While a large part of the discussion among climate scientists focuses on the effect of various policies on the alternative-and more "environmentally friendly"-energy sources, the response of technological change to environmental policy has until very recently been all but ignored by leading economic analyses of environmental policy, which has mostly focused on computable general equilibrium models with exogenous technology ([27], p. 1).

In their empirical work, Arrow et al. [23] follow the procedure of merely adding total factor productivity growth (TFP) to changes in total wealth between two periods-what they call comprehensive investmentand thus assume for practical purposes that technological change is costless and exogenous ("manna from heaven"). It makes a great deal of difference to their empirical results. For example, the US has negative comprehensive investment between two recent time periods if one does not add TFP growth.

For our part, we think one may risk making too optimistic estimates of sustainable development by simply adding TFP growth. Technological change involves investment in research and development (R\&D). Expenditures on $R \& D$ are therefore a part of the change in total wealth between two time periods, and we would prefer to use empirical numbers for such expenditures to assess the role of technology in wealth accounting.

There is also a lack of empirical analyses of this key issue for sustainable development, and more research is needed.

\section{Sustainable Development Indicators for Policymaking: An Example from Norway}

For countries dependent on non-renewable natural capital, transforming natural capital into other forms of wealth is a path to sustainable development. Thus, we will briefly illustrate how this policy area in actual practice is coordinated in a small, open and resourceproducing economy-and how SDIs are used in policy making in Norway $\div$ as we believe this illustrates in concrete and practical terms the usefulness of the analytical framework and the measurements (SDIs) discussed earlier in this paper for actual longer-term development policies.

Earlier in this paper we argued that one needs:

- An analytical framework;

- Measures to assess the sustainability of development;

- Institutions to coordinate longer term policies.

Norway has been a petroleum producing country 
for forty years, and non-renewable resources (oil and gas) presently contribute some 25 per cent of GDP, around one third of total government revenues, and a large share of the surplus of Norway's balance of payments. It would be very misleading to use GDP per capita as a core SDI in Norway, as use of nonrenewable resources, as underlined above, is not subtracted according to present national accounting standards. Norwegian GDP could increase rapidly while drawing down exhaustible resources. Thus wealth accounting, as illustrated in section 3.1 above, and monetized estimates of total or comprehensive wealth and produced capital, market-based natural capital and human capital are presented regularly. In addition Norway has established a national SDI set within a capital framework which also contains some physical indicators of critical natural resources-a Nature Index. An index of life expectancy at birth is used as a proxy for health capital.

Employment is high and unemployment is low in Norway, but a large share of the population of working age is receiving non-working benefits (disability - and sickness benefits), and this is seen as a challenge to longer term sustainability, both as a social issue and because a smaller labour force has to support a rapidly ageing population. Thus, as mentioned above, the number of people on non-working benefits as a share of the working population is used to monitor these aspects. Longer-term fiscal sustainability is also seen as a challenge to sustainability. Therefore, employing generational accounting methods, one may use the deficit as a percentage of GDP in 2060 (under certain assumptions) as an SDI of such conditions.

The Ministry of Finance is the institution responsible for economic and fiscal policies, and is also responsible for coordinating policies to enhance sustainable development. Under this ministry, a saving instrument for the revenues from non-renewable resources (oil and gas), a Sovereign Wealth Fund (SWF) - today named The Government Pension Fund - Global was established in 1990. All revenues from petroleum are placed directly into this fund. In 2001 a savings rule - a fiscal guideline - for domestic use of petroleum revenue was adopted by Parliament.

The Hartwick rule $[28,29]$ provides a simple rule of thumb for sustainable development in countries that depend on non-renewable natural resources. The Hartwick rule holds that consumption can be maintained if the rents from non-renewable resources are continually invested rather than used for current consumption.

The Norwegian fiscal guideline is akin to this rule. Only the rate of return of the stock of financial capital in the Norwegian SWF, which now stands at some 660 billion USD, is to be used domestically for current consumption through the central Government Fiscal Budget. Thus, stocks of Norwegian non-renewable natural resources are transformed into other forms of wealth-a basic rule for sustainable development policies. For more details, see Moe $[30,31]$, The Norwegian National Budget 2013 [32]-the government's main yearly White Paper on economic policies -which contain chapters on both sustainable development and climate change, and the recent Long Term Perspectives for the Norwegian Economy [33].

An important aspect is global sustainability and Norway's contribution to this. To assess this further with regard to climate change, one could use the product of an assumed social cost of carbon multiplied by the amount of $\mathrm{CO}_{2}$ emitted by Norway as an indicator.

\section{Conclusions}

Important elements of sustainable development, like the challenge of climate change, are global problems. Thus, ideally one should have global agreements, indicators, institutions and policies. As of today however, and for the medium term, current policies to sustain present well-being for future generations will probably be largely national with relatively little regional or global cooperation and coordination. Thus, one needs an analytical framework for such policies, national indicators to monitor developments, criteria for assessing sustainability, and national institutions to carry out these tasks.

Each country concerned with policies to enhance sustainable development must chose the framework and set of national indicators best suited for their situation and prospects. We have argued in this paper -based on recent economic literature and Norwegian experiences-that developed countries with established institutions and statistical bases, would benefit from a core national set of SDIs consisting of:

1. Monetary estimates of National or Comprehensive Wealth in real and nominal terms, adjusted for population and technological improvements between periods.

2. Monetary estimates in real terms of real, produced capital (RC), human capital (HC), health capital (one could for simplicity-as is the practice in Norway-simply use estimates of life expectancy) and the market based natural capital base (MNC). Such measures are necessary, but not sufficient, to assess strong sustainability. That is because they do not convey the very real limits to substitutability, impending thresholds for natural capital, or possible irreversibilities and catastrophic events. Thus, indicators are required to assess such conditions and how they develop over time, cf. 3 below.

3. Some indicators in physical terms for the most important or critical elements of non-market natural capital (NMNC) - e.g. climate change, biodiversity based on an ecological approach.

4. Physical indicators of social capital (conditions) and the functioning of institutions-as appropriate 
to the developed country in question.

Even if SDIs under 1 and 2 above increase in real terms per capita, as they presently do in Norway, indicating weak sustainability, we argue that it is also necessary to monitor SDIs under 3-especially critical non-market natural resources-and 4 to see if what we have called non-market capital are on sustainable development paths or not.

For all countries, and especially resource-producing ones, one should compute annual estimates of Adjusted Net Savings (ANS)-as published by The World Bank as a simple macro indicator and check on sustainability. Their estimates published in The Changing Wealth of Nations in 2011 [4] and annually

\section{References}

1. UNECE, OECD, Eurostat. Measuring Sustainable Development. Geneva and New York, Switzerland and USA: United Nations; 2009, pp. 1-124.

2. Stiglitz JE, Sen A, Fitoussi J-P. Report by the Commission on the Measurement of Economic Performance and Social Progress. Available from: www.stiglitz-sen-fitoussi.fr/documents/rapport_ anglais.pdf (assessed on 29 April 2013). Paris, France; 2009. pp. 1-292.

3. World Commission on Environment and Development (WCED). Our Common Future. London, UK: Oxford University Press; 1987.

4. World Bank. The Changing Wealth of Nations. Measuring Sustainable Development in the New Millennium. Washington, DC, USA: World Bank; 2011.

5. Aghion P, Howitt PW. Endogenous Growth Theory. Cambridge Massachusetts, USA: The MIT Press; 1998.

6. Pearce D, Atkinson G. Capital Theory and the Measurement of Development. An Indicator of Weak Sustainability. Ecological Economics. 1993;8(2):103108.

7. Hamilton K, Clemens M. Genuine Saving Rates in Developing Countries. World Bank Economic Review. 1999;13(2):333-356.

8. Dasgupta P, Mäler K-G. Net National Product, Wealth and Social Well-being. Environment and Development Economics. 2000;5:69-93.

9. Pearce D, Atkinson G, Hamilton K. Measuring sustainable development. Progress on indicators. Environment and Economics. 1996;1:85-101.

10. Pearce D, Atkinson G. The Concept of Sustainable Development: An Evaluation of Its usefulness Ten Years After Brundtland. CSERGE Working Paper PA 98-02. London, UK: CSERGE; 1998.

11. Alfsen $\mathrm{KH}$, Moe T. Measuring Sustainable Development. Oslo, Norway: The Norwegian Ministry of Finance; 2008.

12. Hamilton K, Atkinson G. Wealth, Welfare and Sustainability. Advances in Measuring Sustainable development. Cheltenham, UK: Edward Elgar in their World Development Indicators, show negative adjusted net savings for a number of developing countries-especially resource-producing countries in Africa-which is an indication of non-sustainable development paths. Especially for resource-producing developing countries, it would be useful to compute ANS regularly, possibly each year in addition to GDP, to get an annual check on whether the country in question is on a sustainable path. In any case, there is logic for extractive economies such as Norway in using a "depletion-adjusted" measure of net saving, such as ANS. The new SEEA central framework [34] suggests this as an aggregate sustainability indicator.

Publishing; 2006.

13. Eurostat. Accounts for Subsoil Assets - Results of Pilot Studies in European countries. Luxembourg: ISBN 92-894-0056-0, 2000.

14. United Nations, European Commission, OECD, World Bank. Handbook of National Accounting. Integrated Environmental and Economic Accounting. Studies in Methods. Series F 61/Rev.1. New York, NY, USA: United Nations; 2003.

15. Jorgenson D, Fraumeini BM. The Output of the Education Sector. In: Grilliches, Z, editor. Output measurement in the Service Sectors. Chicago, USA: University of Chicago press; 1992.

16. Stroombergen A, Rose D, Nana G. Review of the Statistical Measurement of Human Capital. Wellington, New Zealand: Statistics New Zealand; 2002.

17. Greaker M. National Wealth and the Calculation of the Human Capital Component. Geneva, Switzerland; Economic Commission for Europe. Working Paper 7; 2007. pp 1-19. Available from: http://www.unece.org/fileadmin/DAM/stats/document s/ece/ces/ge.32/2007/wp.7.e.pdf (assessed. on 29 April 2013).

18. Greaker M, Liu G. Measuring the Stock of Human Capital for Norway - A Lifetime Labour income approach. Oslo, Norway: Statistics Norway. Documents 2009/12; 2009. Available from: http:// www.ssb.no/a/english/publikasjoner/pdf/doc_200912_ en/doc_200912_en.pdf (assessed on 29 April 2013).

19. UNECE Conference of European Statisticians. Measuring Human capital. Stock-Taking Report ECE/CES/BUR/2012/NOV/11. Geneva, Switzerland: Conference of European Statisticians; 2012.

20. OECD. The Well-Being of Nations. The Role of Human and Social Capital. Paris, France: OECD; 2001.

21. Pearce D, Barbier E. Blueprint for a Sustainable Economy. London, UK: Earthscan Publications Ltd.; 2000.

22. Rockstrøm J, Steffen W, Noone K, Persson $\AA$, Chapin FS III, Lambin EF, Lenton TM, Scheffer $M$, Folke C, Schellnuber HJ, Nykvist B, de Wit CA, Hughes T, van der Leeuw S, Rodhe H, Sörlin S, Snyder PK, 
Costanza R, Svedin U, Falkenmark M, Karlberg L, Corell RW, Fabry VJ, Hansen J, Walker B, Liverman D, Richardson K, Crutzen P, Foley JA. A Safe Operating Space for Humanity. Nature. 2009;461:472-475. DOI:10.1038/461472a.

23. Arrow KJ, Dasgupta P, Goulder LH, Mumford KJ, Oleson K. Sustainability and the Measurement of Wealth. Environment and Development Economics. 2012;17(3):317-353.

24. Hamilton K. Comments on Arrow et al., 'Sustainability and the measurements of wealth'. Environment and Development Economics. 2012; 17(3):356-361.

25. d'Ercole MM, Salvini A. Towards Sustainable Development: The Role of Social Protection. Social, Employment and Migration. Paris, France: OECD; Working Paper No. 52; 2003.

26. World Bank. Where is the Wealth of Nations? Measuring capital for the 21th Century. Washington, DC, USA: World Bank; 2006.

27. Acemoglu D, Aghion P, Bursztyn L, Hemons, D. The Environment and Directed Technological Change. The American Economic Review. 2009;102(1):131166. Available from: http://hdl.handle.net/1721.1/ 61749 (assessed on 29 April 2013).

28. Hartwick JM. Intergenerational Equity and the Investing of Rents from Exhaustible Resources.
American Economic Review. 1977;67(5):972-974.

29. Solow R. On the Intergenerational Allocation of Natural Resources. Scandinavian Journal of Economics. 1986;88(1):141-149.

30. Moe T. The Norwegian model of sustainable development. A Policy Oriented Capital Framework for Measurement and Policies. Oslo, Norway: The Norwegian Ministry of Finance; 2007.

31. Moe T. Wealth, Welfare and Sustainable Growth and Development: Challenges for Economic and Fiscal Policies in Resource-Producing Countries. Oslo, Norway: CICERO. Cicero Policy Note 2011:01; 2011.

32. Norwegian Ministry of Finance. The National Budget 2013. White Paper No. 1 (2012-2013). Chapter 7 Sustainable development, 2012;133-148.

33. Norwegian Ministry of Finance. Long term perspectives for the Norwegian Economy. White Paper No. 12 (2012-2013); 2013.

34. European Commission, Food and Agriculture Organization, International Monetary Fund, Organisation for Economic Co-operation and Development, United Nations, World Bank. System of Environmental-Economic Accounting (SEEA). Central Framework. Available from: https://unstats.un.org/unsd/ envaccounting/White_cover.pdf (assessed on 29 April 2013). 